\title{
Penilaian Risiko Penularan Covid-19 pada Peserta Didik di Kampung Inggris Menggunakan Aplikasi InaRisk
}

\author{
Dewi 'Izzatus Tsamroh ${ }^{1 *}$, Nika Devi Permata Wijaya² dan Anisa Zuhria Sugeha ${ }^{3}$ \\ ${ }^{1}$ Prodi S1 Teknik Mesin, Fakultas Teknik, Universitas Merdeka Malang, Jalan Terusan Raya Dieng 62-64 \\ Malang, Indonesia, 65146 \\ ${ }^{2}$ Prodi S1 Teknik Sipil, Fakultas Teknik, Universitas Merdeka Malang, Jalan Terusan Raya Dieng 62-64 \\ Malang, Indonesia, 65146 \\ ${ }^{3}$ Prodi D3 Perhotelan, Diploma Kepariwisataan, Universitas Merdeka Malang, Jalan Bandung 1a, Malang, \\ Indonesia, 65113
}

Correspondence: Dewi ‘Izzatus Tsamroh (izza@unmer.ac.id)

Received: 30 Juni 2021 - Revised: 01 Agustus 2021 - Accepted: 16 Agustus 2021

\begin{abstract}
Abstrak. Covid-19 adalah penyakit yang disebabkan oleh varian virus baru yang kemudian dinamakan $S A R S-C o V-2$. Penyakit ini mewabah dari Wuhan, Hubei, Cina ke seluruh dunia, dan ditetapkan sebagai pandemi oleh WHO, dan di Indonesia sendiri wabah ini ditetapkan sebagai bencana nasional. Pemerintah telah memberlakukan kebijakan untuk menekan penularan covid-19 termasuk penerapan protokol kesehatan yang ketat. Seiring berjalannya waktu, kesadaran masyarakat untuk menerapkan protokol kesehatan semakin berkurang. Tujuan kegiatan pengabdian masyarakat ini adalah untuk mengedukasi masyarakat, khususnya di Kampung Inggris Pare mengenai risiko penularan covid-19, serta penilaian mandiri, dan upaya pencegahan penularan covid-19. Kegiatan ini dilakukan dengan menggunakan metode pendidikan masyarakat. Hasil kegiatan menunjukkan bahwa sebagian besar status risiko penularan covid-19 di Kampung Inggris rendah, yaitu sebesar 56\%. Akan tetapi, masih ditemui 40\% dengan status risiko sedang, dan 4\% dengan status risiko tinggi. Hal ini disebabkan adanya pola perilaku peserta didik di Kampung Inggris yang masih abai dengan protokol kesehatan.
\end{abstract}

Kata kunci: Penilaian mandiri, penularan, covid-19, InaRisk Personal, Kampung Inggris

Citation Format: Tsamroh, D.I., Wijaya, N.D.P. \& Sugeha, A.Z. (2021). Penilaian Risiko Penularan Covid-19 pada Peserta Didik di Kampung Inggris Menggunakan Aplikasi InaRisk. Prosiding Seminar Nasional Abdimas Ma Chung (SENAM), 231-239. 


\section{PENDAHULUAN}

Coronavirus Disease 2019 yang kemudian dikenal sebagai Covid-19 adalah jenis virus baru yang mewabah sejak awal tahun 2020 (Syaputra et al., 2021). Virus baru dari keluarga Corona ini diberi nama Severe Acute Respiratory Syndrome Coronavirus 2 atau SARS-CoV-2 (Caesaron et al., 2021). Virus menular ini pertama kali ditemukan di Wuhan, Hubei, Cina pada akhir tahun 2019 yang menginfeksi saluran pernapasan manusia (Evans, 2020). Mewabahnya virus ini kemudian ditetapkan oleh WHO sebagai Public Health Emergency of International Concern (PHEIC) sejak tanggal 30 Januari 2020 (Syapitri et al., 2020).

Virus ini dapat menular dengan mudah melalui droplet, sehingga penyebarannya sangat cepat. Hampir 200 negara di dunia terjangkit virus ini tak terkecuali di Indonesia (Syaputra et al., 2021). Kasus yang terus bertambah hingga bulan Maret 2020, maka wabah ini ditetapkan oleh Presiden Joko Widodo sebagai Bencana Nasional (Keputusan Presiden Republik Indonesia Nomor 12 Tahun 2020, 2020). Menghadapi penyebaran virus yang sangat cepat, pemerintah telah memberlakukan lockdown dan PSBB (Hastuti et al., 2020), bahkan karena kasus yang belum kian menurun pemerintah memberlakukan PPKM mikro hingga PPKM darurat.

Pemberlakuan lockdown, PSBB, PPKM mikro, hingga PPKM darurat memberikan dampak pada berbagai faktor, terutama faktor ekonomi (Sufiyanto et al., 2020), pendidikan, hingga pariwisata (Sugihamretha, 2020). Kampung Inggris, yang terletak di Desa Singgahan dan Desa Tulungrejo, Pare, Kediri yang terkenal sebagai kampung pendidikan Bahasa Inggris sekaligus kampung wisata, turut merasakan dampak dari munculnya wabah covid-19 ini. Pada awal pemberlakuan kebijakan lockdown dan PSBB pada tahun 2020, seluruh peserta didik dipulangkan. Hal ini tentunya berpengaruh buruk terhadap kehidupan sosial ekonomi penduduk di Kampung Inggris, karena banyak penduduk yang menggantungkan pendapatan ekonominya dari berjualan makanan, penyedia rumah kost, laundry, hingga persewaan sepeda (Mu'arifa, 2020).

Pada awal tahun 2021, beberapa lembaga kursus di Kampung Inggris telah mendapatkan ijin operasional dari Dinas Kesehatan Kabupaten Kediri dengan syarat dapat menerapkan protokol kesehatan yang baik (Pare, 2021). Tentunya hal ini membawa berita yang baik bagi penduduk sekitar, dengan demikian usaha mereka dapat kembali berjalan. Akan tetapi, seiring berjalannya waktu, penerapan protokol kesehatan semakin longgar, 
termasuk di berbagai café dan tempat nongkrong yang ada di Kampung Inggris. Dimana kapasitas pengunjung tidak diperhatikan, tidak menjaga jarak, dan banyak ditemui pengunjung café yang tidak mengenakan masker. Hal ini menunjukkan bahwa kesadaran penduduk dan peserta didik di kampung Inggris mengenai resiko penularan covid-19 cenderung rendah.

Menghadapi permasalahan ini, pemerintah telah melaksanakan berbagai macam upaya, salah satunya yang dilakukan oleh Badan Nasional Penanggulangan Bencana (BNBP) dengan merilis aplikasi InaRisk Personal sejak awal munculnya covid-19 (Simanjuntak et al., 2021). Melalui aplikasi ini, pemantauan indeks risiko bencana dapat dipantau oleh pemerintah termasuk covid-19. InaRisk Personal ini merupakan aplikasi yang dapat dioperasikan oleh masyarakat luas. Pengguna, dalam hal ini masyarakat berperan sebagai responden yang dapat memberikan data dengan mengisi kuesioner yang ada dalam aplikasi tersebut (Sufiyanto et al., 2020). Output dari aplikasi ini, pengguna dapat menilai mengenai risiko dirinya terhadap penularan covid-19 (Sriningsih et al., 2020). Selain itu, dengan mengetahui tingkat risiko, maka pengguna dapat melakukan halhal sebagai upaya pencegahan penularan covid-19 (Ngaini et al., 2020).

Berdasarkan pemaparan di atas, maka kegiatan pengabdian kepada masyarakat dengan menggunakan aplikasi InaRisk Personal dilakukan di Kampung Inggris selama PPKM darurat, bertujuan sebagai berikut: (1) memberikan edukasi kepada peserta didik di Kampung Inggris mengenai risiko penularan covid-19, (2) memberikan edukasi mengenai penilaian mandiri terhadap risiko penularan covid-19 serta rekomendasi upaya pencegahan penularan covid-19.

\section{MASALAH}

Permasalahan yang ditemui adalah rendahnya kesadaran penduduk dan peserta didik di Kampung Inggris mengenai risiko penularan covid-19. Hal ini ditunjukkan dengan banyaknya café yang buka dengan penerapan protokol kesehatan yang kurang baik (tidak menyediakan pemeriksaan suhu, tempat cuci tangan dan handsanitizer) (Mukarom, 2021), peserta didik yang kerap berkerumun, tidak mengenakan masker, dan tidak menjaga jarak. Dengan demikian, diperlukan suatu usaha untuk mensosialisasikan dan mengedukasi masyarakat melalui penilaian mandiri mengenai risiko penularan covid-19 dengan menggunakan aplikasi InaRisk Personal. 


\section{METODE PELAKSANAAN}

Metode yang digunakan dalam kegiatan pengabdian kepada masyarakat ini adalah dengan menerapkan metode pendidikan masyarakat. Metode pendidikan masyarakat digunakan untuk kegiatan-kegiatan seperti pelatihan semacam in-house training, penyuluhan yang bertujuan meningkatkan pemahaman serta kesadaran, dan sebagainya. Teknik pengambilan sampel menggunakan teknik simple random sample, dimana sampel diambil pada peserta didik di Kampung Inggris. Teknik pengumpulan data dilakukan dengan menggunakan kuesioner pada aplikasi InaRisk Personal. Teknik analisis data yang digunakan dalam kegiatan ini adalah analisis deskriptif. Lokasi kegiatan dilakukan di Desa Tulungrejo, Pare, Kediri pada tanggal 5-6 Juli 2021.

\section{HASIL DAN PEMBAHASAN}

\section{Karakteristik Responden}

Tabel 1. Distribusi Frekuensi Berdasarkan Karakteristik Responden $(n=50)$

\begin{tabular}{cccc}
\hline Karakteristik & & F & $\%$ \\
\hline Usia & $<20$ tahun & 12 & 24 \\
& $20-30$ & 38 & 76 \\
\multirow{3}{*}{ Jenis Kelamin } & Laki-laki & 27 & 54 \\
& Perempuan & 23 & 23 \\
\hline Total & & 50 & 100
\end{tabular}

Berdasasarkan paparan data pada Tabel 1, maka dapat diketahui bahwa data didominasi oleh responden yang berusia pada rentang 20-30 tahun, yaitu sebesar 76\% sebanyak 39 orang. Sedangkan berdasarkan jenis kelamin, didominasi oleh laki-laki dengan persentase sebesar 54\% yang terdiri dari 27 orang. Observasi awal menunjukkan bahwa hanya 1 orang dari 50 responden yang mengetahui tentang aplikasi InaRisk Personal.

\section{Potensi Tertular di Luar Rumah}

Tabel 2. Distribusi Frekuensi Berdasarkan Pernyataan Potensi Tertular di Luar Rumah ( $\mathrm{n}=50$ )

\begin{tabular}{clccc}
\hline No & \multicolumn{1}{c}{ Pernyataan } & Kriteria & $\mathrm{F}$ & $\%$ \\
\hline 1 & Saya pergi keluar rumah. & Ya $(1)$ & 41 & 82 \\
& & $\operatorname{Tidak}(2)$ & 9 & 28 \\
2 & Saya menggunakan transportasi umum: online, & Ya $(1)$ & 13 & 26 \\
& angkot, bus, taxi, kereta api. & $\operatorname{Tidak}(2)$ & 37 & 74 \\
3 & Saya tidak memakai masker pada saaat & Ya (1) & 43 & 86
\end{tabular}


berkumpul dengan orang lain.

4 Saya berjabat tangan dengan orang lain.

5 Saya tidak membersihkan tangan dengan hand sanitizer/tissue basah sebelum pegang kemudi mobil/motor.

6 Saya menyentuh benda/uang yang juga disentuh orang lain.

7 Saya tidak menjaga jarak 1,5 meter dengan orang lain ketika: belanja, bekerja, belajar, ibadah.

8 Saya makan di luar rumah (warung/restaurant).

9 Saya tidak minum hangat dan mencuci tangan menggunakan sabun saat tiba di tujuan.

10 Saya berada di wilayah tempat pasien covid-19 tertular.

$\begin{array}{ccc}\text { Tidak(2) } & 7 & 14 \\ \text { Ya (1) } & 25 & 50 \\ \text { Tidak(2) } & 25 & 50 \\ \text { Ya (1) } & 20 & 40 \\ \text { Tidak(2) } & 30 & 60 \\ \text { Ya (1) } & 38 & 76 \\ \text { Tidak(2) } & 12 & 24 \\ \text { Ya (1) } & 27 & 54 \\ \text { Tidak (2) } & 23 & 46 \\ \text { Ya (1) } & 22 & 44 \\ \text { Tidak(2) } & 28 & 56 \\ \text { Ya (1) } & 5 & 10 \\ \text { Tidak(2) } & 45 & 90 \\ \text { Ya (1) } & 2 & 4 \\ \text { Tidak(2) } & 48 & 96\end{array}$

Berdasarkan paparan data pada Tabel 2, maka dapat diketahui bahwa peserta didik di Kampung Inggris memiliki risiko terpapar covid-19 berdasarkan potensi tertular di luar rumah. Terdapat 5 pernyataan yang menunjukkan perilaku responden dengan persentase $\geq 50 \%$, dimana sebagian besar responden melakukan aktivitas pergi keluar rumah (82\%), tidak mengenakan masker saat berkumpul dengan orang lain (86\%), melakukan jabat tangan dengan orang lain (50\%), menyentuh benda/uang yang juga disentuh orang lain (76\%), tidak menjaga jarak (54\%). Keadaan ini menunjukkan bahwa responden tergolong di usia muda yang memiliki mobilitas/aktivitas di luar rumah, berkumpul dengan orang lain (nongkrong di café atau tempat makan), serta tidak menjaga jarak. Tentunya pola perilaku ini menyebabkan responden rentan tertular covid-19. Hasil kegiatan lain dengan menggunakan aplikasi InaRisk, menunjukkan bahwa terdapat 3 pola penyebab risiko tertular di luar rumah, yaitu menyentuh benda yang disentuh oleh orang lain (89\%), pergi ke luar rumah (86,3\%), serta berjabat tangan (46,3\%) (Sufiyanto et al., 2020).

\section{Potensi Tertular di Dalam Rumah}

Tabel 3. Distribusi Frekuensi Berdasarkan Pernyataan Potensi Tertular di Dalam Rumah ( $\mathrm{n}=50)$

\begin{tabular}{clccc}
\hline No & \multicolumn{1}{c}{ Pernyataan } & Kriteria & F & $\%$ \\
\hline 1 & Saya tidak pasang hand sanitizer di depan pintu & Ya (1) & 18 & 36 \\
& masuk, untuk bersihkan tangan sebelum pegang & Tidak (2) & 32 & 64 \\
& gagang (handle pintu masuk rumah) & & & \\
2 & Saya tidak mencuci tangan dengan sabun & Ya (1) & 11 & 22 \\
& setelah tiba di rumah. & Tidak(2) & 39 & 78 \\
3 & Saya tidak menyediakan: tissue & Ya (1) & 6 & 12 \\
& basah/antiseptic, masker, sabun & Tidak (2) & 44 & 88
\end{tabular}




\begin{tabular}{clccc}
\hline No & \multicolumn{1}{c}{ Pernyataan } & Kriteria & F & $\%$ \\
\hline \multirow{2}{*}{4} & $\begin{array}{l}\text { antiseptic bagi keluarga di rumah. } \\
\text { Saya tidak segera merendam baju dan } \\
\text { celana bekas pakai di luar rumah ke } \\
\text { dalam air panas/sabun. }\end{array}$ & Ya (1) & 24 & 48 \\
5 & $\begin{array}{l}\text { Saya tidak segera mandi keramas } \\
\text { setelah saya tiba di rumah. }\end{array}$ & Tidak (2) & 26 & 52 \\
& Ya (1) & 21 & 42 \\
6 & $\begin{array}{l}\text { Saya tidak mensosialisasikan check list } \\
\text { penilaian risiko pribadi ini kepada } \\
\text { keluarga di rumah. }\end{array}$ & Tidak (2) & 29 & 58 \\
& Ya (1) & 15 & 30 \\
& Tidak (2) & 35 & 70 \\
\hline
\end{tabular}

Berdasarkan paparan data pada Tabel 3, maka dapat diketahui bahwa peserta didik di Kampung Inggris memiliki risiko yang cukup rendah terpapar covid-19 berdasarkan potensi tertular di dalam rumah. Responden sebagian besar memasang hand sanitizer di depan pintu masuk untuk digunakan sebelum memegang gagang pintu (64\%), mencuci tangan setelah tiba di rumah (78\%), serta menyediakan tissue basah/antiseptic, masker, sabun antiseptic bagi keluarga di rumah (88\%). Perilaku ini telah sesuai dengan rekomendasi WHO, dimana secara rutin mencuci tangan menggunakan alkohol, sabun maupun air penting dilakukan merupakan proteksi dasar (Simanjuntak et al., 2021; Xu et al., 2021). Berdasarkan penelitian terdahulu, diketahui bahwa 50\% anggota keluarga di rumah tertular oleh anggota keluarga yang positif covid-19, oleh sebab itu, potensi penularan di dalam rumah sangat perlu diperhatikan (Kiran, 2020).

\section{Daya Tahan Tubuh}

Tabel 4. Distribusi Frekuensi Berdasarkan Pernyataan Daya Tahan Tubuh ( $\mathrm{n}=50)$

\begin{tabular}{clccc}
\hline No & \multicolumn{1}{c}{ Pernyataan } & Kriteria & F & $\%$ \\
\hline 1 & Saya dalam sehari tidak terkena sinar matahari & Ya (1) & 9 & 18 \\
& minimal 15 menit. & Tidak (2) & 41 & 82 \\
2 & Saya tidak jalan kaki/berolah raga minimal 30 & Ya (1) & 12 & 24 \\
& menit setiap hari. & Tidak(2) & 38 & 76 \\
3 & Saya tidak minum vitamin C \& E, dan & Ya (1) & 16 & 32 \\
& kurang tidur. & Tidak (2) & 34 & 68 \\
4 & Usia saya di atas 60 tahun. & Ya (1) & 0 & 0 \\
& & Tidak (2) & 50 & 100 \\
5 & Saya mempunyai penyakit & Ya (1) & 1 & 2 \\
& jantung/diabetes/gangguan pernafasan & Tidak (2) & 49 & 98 \\
& kronik. & & &
\end{tabular}

Berdasarkan paparan data pada Tabel 4, menunjukkan bahwa sebagian besar responden tidak terkena sinar matahari selama 15 menit dalam sehari (82\%), responden tidak melakukan olahraga ringan selama 30 menit (76\%), responden tidak memiliki penyakit bawaan yang bersifat kronis: jantung/diabetes/gangguan pernafasan kronik 
(98\%), responden minum vitamin C \& E, dan tidak kurang tidur (68\%) serta tidak ada responden yang berusia lebih dari 60 tahun (0\%). Faktor risiko terpapar covid-19 akan berpeluang besar pada kelompok usia di atas 60 tahun dan yang memiliki komorbid (penyakit bawaan) (Susilo et al., 2020).

\section{Status Risiko}
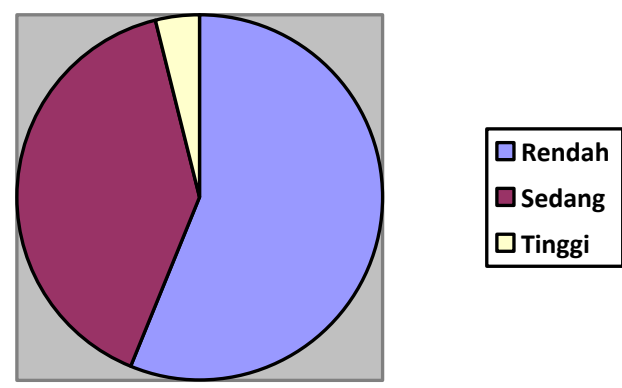

Gambar 1. Presentase status risiko responden.

Berdasarkan Gambar 1, maka dapat diketahui bahwa 56\% responden dengan jumlah 28 orang memiliki status risiko rendah, $40 \%$ responden dengan jumlah 20 orang memiliki status risiko sedang, dan $4 \%$ responden dengan jumlah 2 orang memiliki status risiko tinggi. Dengan demikian dapat diketahui bahwa hampir 50\% peserta didik di Kampung Inggris berpotensi untuk tertular covid-19.

\section{KESIMPULAN}

Berdasarkan hasil kegiatan pengabdian kepada masyarakat yang dilaksanakan di Kampung Inggris, maka dapat disimpulkan bahwa sebagian besar status risiko penularan covid-19 di Kampung Inggris rendah, yaitu sebesar 56\%. Akan tetapi, masih ditemui 40\% dengan status risiko sedang, dan 4\% dengan status risiko tinggi. Hal ini disebabkan adanya pola perilaku peserta didik di Kampung Inggris yang masih abai dengan protokol kesehatan.

\section{UCAPAN TERIMA KASIH}

Ucapan terima kasih ditujukan kepada LPPM Universitas Merdeka Malang yang telah memberikan fasilitas untuk mengikuti Seminar Nasional Abdimas Ma-Chung Tahun 2021. 


\section{DAFTAR PUSTAKA}

Caesaron, D., Salma, S. A., Prasetyo, M. D., \& Rifai, M. H. (2021). Edukasi dan Sosialisasi Pencegahan dan Pengendalian COVID-19 melalui Media Poster di Desa Bojongsoang , Kabupaten Bandung. 6(May), 221-229.

Evans, M. (2020, January). COVID-19: What you need to know about coronavirus. Patient. https://patient.info/news-and-features/covid-19-what-you-need-to-know-aboutcoronavirus

Hastuti, P., Harefa, D. N., \& Napitupulu, J. I. M. (2020). Tinjauan Kebijakan Pemberlakuan Lockdown, PHK, PSBB sebagai Antisipasi Penyebaran Covid-19 Terhadap Stabilitas Sistem Moneter. Prosiding Webinar Fakultas Ekonomi Universitas Negeri Medan.

Keputusan Presiden Republik Indonesia Nomor 12 Tahun 2020, 1 (2020).

Kiran, S. (2020). Occupational Health Could be the New Normal Challenge in the Trade and Health Cycle: Keywords Analysis Between 1990 and 2020. Safety and Health at Work, 0-4. https://doi.org/10.1016/j.shaw.2020.11.003

Mu'arifa, N. (2020). Kampung Inggris dan Implikasinya Terhadap Sosial Ekonomi Masyarakat (Studi pada Dusun Singgahan, Desa Pelem dan Desa Tulungrejo, Pare, Kabupaten Kediri). Jurnal Ilmiah Mahasiswa FEB UB, 8(1).

Mukarom, F. (2021). Bupati Kediri Beri Peringatan 10 Kafe di Pare yang Langgar Aturan PPKM Darurat. Surya.Co.Id. https://surabaya.tribunnews.com/2021/07/12/bupatikediri-beri-peringatan-10-kafe-di-pare-yang-langgar-aturan-ppkm-darurat

Ngaini, F., Sutrisno, E., Wildan, T., Nurhairiyawati, A., \& Tiyas, V. Y. (2020). Pemetaan Risiko Terhadap Covid-19 Berbasis Sistem Informasi Geografis (SIG) Menggunakan Aplikasi Inarisk Personal (Vol. 2019).

Pare, H. 2. (2021). PSBB Kampung Inggris Pare 2021-HEC 2 Tetap Buka Pendaftaran. https://hec2pare.com/psbb-kampung-inggris-pare-2021-hec-2-tetap-buka-pendaftaran/

Simanjuntak, E. Y., Octavia, Y. T., \& Romayanti, Y. (2021). Gambaran resiko penularan covid-19 menggunakan self assessment inarisk pada mahasiswa keperawatan. Jurnal Gawat Darurat, 3(1), 53-62.

Sriningsih, S., N, I. U., \& Fajrin, N. (2020). Sosialisasi Pengisian Penilaian Mandiri Melalui Aplikasi Inarisk Personal Sebagai Pemetaan Risiko Covid-19 di Wilayah Desa.

Sufiyanto, S., Yuniarti, S., \& Andrijono, D. (2020). Sosialisasi dan Edukasi Penilaian Mandiri terhadap Risiko Penularan COVID-19 melalui InaRISK Personal. 5(November), 209-219.

Sugihamretha, I. D. G. (2020). Respon Kebijakan : Mitigasi Dampak Wabah Covid-19 Pada Sektor Pariwisata Respon Kebijakan : Mitigasi Dampak Wabah Covid-19 Pada Sektor Pariwisata. The Indonesian Journal of Development Planning, IV(2), 191-206.

Susilo, A., Rumende, C. M., Pitoyo, C. W., Santoso, W. D., Yulianti, M., Sinto, R., Singh, G., Nainggolan, L., Nelwan, E. J., Khie, L., Widhani, A., Wijaya, E., Wicaksana, B., 
Maksum, M., Annisa, F., Jasirwan, O. M., Yunihastuti, E., Penanganan, T., New, I., ... Cipto, R. (2020). Coronavirus Disease 2019: Tinjauan Literatur Terkini Coronavirus Disease 2019. Review of Current Literatures. 7(1), 45-67.

Syapitri, H., Siregar, L. M., \& Saragih, F. L. (2020). Pencegahan Penularan Covid-19 Melalui Sosialisasi dan Pembagian Masker di Pasar Pringgan Medan. Jurnal Kreativitas Pengabidan Kepada Masyarakat (PKM), 3, 422-429.

Syaputra, H. E., S, O. D. P., Sari, S. N., Akuntansi, P., Perpustakaan, P. I., Ekonomi, F., \& Sari, U. (2021). Sosialisasi INARISK sebagai Upaya Pencegahan dan Percepatan Penanganan Covid-19 pada Masyarakat Kecamatan Medan Helvetia Kota Medan, Jurnal Abdimas Mutiara, 2(1), 108-113.

Xu, H., Zhang, M., \& Hudson, A. (2021). Occupational Health Protection for Health Workers in China With Lessons Learned From the UK: Qualitative Interview and Policy Analysis. Safety and Health at Work, 9.

https://doi.org/10.1016/j.shaw.2021.02.002

\section{(c) (i)}

(C) 2021 by authors. Content on this article is licensed under a Creative Commons Attribution 4.0 International license. (http://creativecommons.org/licenses/by/4.0/). 